\title{
Zelulosa-nanokristaletan oinarritutako material nanokonposatuak
}

\author{
Cellulose nanocrystal based nanocomposite materials
}

\author{
Uribarri Goikuria*1, Erlantz Lizundia ${ }^{1,2}$ \\ ${ }^{1}$ Kimika Fisika Saila, Kimika Makromolekularreko Laborategia. \\ Euskal Herriko Unibertsitatea (UPV/EHU) \\ ${ }^{2}$ Adierazpen Grafikoa eta Ingeniaritzako Proiektuak Saila . \\ Euskal Herriko Unibertsitatea (UPV/EHU)
}

\begin{abstract}
LABURPENA: Gaur egungo plastiko erabilienak oraindik petroliotik deribatutako polimero eta lehengaietan oinarrituta daude, horrek ingurumenean duen eragina eta guzti, material horiek biodegradagarriak ez direlako, besteak beste. Egoera honetan, erakunde eta industria sektore askotan, gero eta erregulazio eta estandar gehiago ezartzen ari dira, produktu jasankorragoak eta ingurumenarekiko aproposagoak garatzea bultzatzeko helburuan. Honen eraginez, polimero biodegradagarrien inguruan interes handia piztu da, eta material horien aukerak sakonki ikertzen ari dira. Polimero biodegradagarri mota desberdinak daude eta horrez gain, polimero berriak aurkitzeko eta garatzeko asmoarekin, oinarrizko materialen inguruan aukera desberdinak aztertzen ari dira. Ikerketa zabal honi esker, material polimeriko biodegradagarrien arloan propietate berri eta interesgarriak agertzen ari dira eta honekin lotuta aplikazioa askotarako aukerak. Material biodegradagarrien artean, zelulosatik deribatutakoak nabarmendu daitezke; zelulosak jatorri naturala du, material oparoenetariko bat da eta ezaugarri apartak azaltzen ditu. Zelulosa eta horren propietate bereziak aspaldi ezagunak diren arren, gaur egun ikerkuntza-arlo emankor bat zabaldu da zelulosatik sintetizatutako eskala nanometrikoko materialen inguruan, material horiek agertzen dituzten propietate ikusgarrien eta funtzionalizazio-aukeren ondorioz. nanozelulosa mota desberdinak lor daitezke, zelulosa-nanozuntzak (ZNZak), zelulosa-nanokristal (ZNKak) eta nanozelulosa bakterianoa (NZBa). Nanozelulosa mota bakoitzak xehetasun partikularrak ditu, propietate bereziak eta berezitasun hauen ondorioz aplikazio arlo ugari agertzen ari dira, etorkizun nabarmena eskainiz. Bestalde, aplikazioaren arabera ez ezik materialak oinarrizko egituraren distribuzioaren arabera sailkatzen baditugu, nanozelulosan oinarritutako materialak hidrogel, aerogel edo film bezala aurkitu dezakegu. Zehazki, nanozelulosan oinarritutako aerogelak emaitza ikusgarriak ematen ari dira, horien pisu arin eta dentsitate baxu, porositate altu eta propietate mekaniko paregabeen ondorioz besteak beste. Propietate horri zelulosaren biobateragarritasuna, toxikotasunik eza eta biodegradagarritasuna gehitzen badizkiogu, material interesgarriak lor daitezke, funtzionalizazio- eta kustomizazio-aukera zabalak dituztenak. Pertsonalizazio-aukeren eta ezaugarri aparten ondorioz, nanozelulosa eta nanozelulosan oinarritutako materialak zenbait sektoretan hasi dira erabiltzen; besteak beste ingurumenean, energian, biomedikuntzan, enbalatze eta elikadura industrietan edo garraioan.
\end{abstract}

HITZ GAKOAK: biomaterialak, polimero biodegradagarriak, nanozelulosa, zelulosa-nanokristalak, nanozuntzak, funtzionalizazioa, biobateragarritasuna, porotasuna, nanokonpositeak, aerogelak

\begin{abstract}
Nowadays, most of the commonly used polymers are derived from petrochemical resources, representing serious environmental issues due their non-biodegradability. In this framework, governments and different industrial sectors are stablishing regulations and standards towards a transition to a green economy and for the prospective development of environmentally sustainable products. As a consequence, the interest on biodegradable polymers is rapidly increasing. Among the different kind of biodegradable polymers, cellulose derived ones represent an outstanding opportunity due to their natural origin, their abundance in nature and their special properties. Eventhough cellulose and its characteristics are well known, currently cellulose derived nanoscale materials are being thoroughly studied due to the extraordinary properties that these materials are showing. Different types of nanocellulose could be synthesize, such as cellulose nanofibers (CNF), cellulose nanocrystals $(C N C)$ and bacterial nanocellulose (BNC). Each nanocellulose type has their particular features, unusual properties, a wide range of application fields and thus an extraordinary future is expected for these materials. In this line, according not only to the application and considering the internal structure distribution, nanocellulose could be obtained into different shapes, such as hydrogels, aerogels or films. Particularly, nanocellulose based aerogels are providing extraordinary results owing to the low weight and density, high porosity and good mechanical properties, among other unusual properties. Combining these properties with the biocompatibility, non toxicity and biodegradability, nanocellulose represents a good chance to achieve fabulous materials with great functionalization and customization possibilities. As a consequence of this customization posibilities and these great properties, nanocellulose and nanocellulose based materials are being used in environment, energy, biohealth, packaging and food industry or transport sector among other aplication fields.
\end{abstract}

KEYWORDS: biomaterials, biodegradable polymers, nanocellulose, cellulose nanocrystals, nanofibers, functionalization, biocompatibility, porosity, nanocomposites, aerogels.

* Harremanetan jartzeko / Corresponding author: Uribarri Goikuria. Kimika Fisika Saila, Kimika Makromolekularreko Laborategia,Euskal Herriko Unibertsitatea (UPV/EHU), Sarriena Auzoa, 48940 Leioa. - ugoikuria@ehu.eus - https://orcid. org/0000-0002-5108-5011.

Nola aipatu / How to cite: Goikuria, Uribarri; Lizundia, Erlantz (2019). «Zelulosa-nanokristaletan oinarritutako material nanokonposatuak»; Ekaia, 35, 2019, 119-142. (https://doi.org/10.1387/ekaia.19675).

Jasoa: 11 maiatza, 2018; Onartua: 18 iraila, 2018

ISSN 0214-9001 - eISSN 2444-3255 / (c) 2019 UPV/EHU

(c) (i) (2) Obra hau Creative Commons Atribución 4.0 Internacional-en

(cc) $\mathrm{BY}$ NC $\mathrm{SA}_{\mathbf{A}}$ lizentziapean dago 


\section{POLIMERO BIODEGRADAGARRIAK ETA BIOPOLIMEROAK}

Jakina da plastikoen erabilera oso arrakastatsua izan dela, bereziki enbalatzeko material bezala. Baina enbalatzeko plastiko gehienek bizi-ziklo oso laburra dute, eta, ondorioz, ezabatze-bolumen handia eta ezabatze-denbora luzea. Mundu mailan urtero 300 milioi tona inguru sortzen dira eta kopuru horrek etengabeko gorakada izan du azkenengo 15 urteetan. Kopuru horren \% 30ek bizi- ziklo laburra dauka, eta soilik $\% 9$ birziklatzen da: \% 12 inguru erraustu egiten da, eta \% 79 hondakindegietara edo ingurumenera eta, bereziki, itsasora iristen da, 100 urte baino gehiagoko desagerpen-denborekin [1]. Plastikoak osatzen dituzten polimero gehienak petroliotik eratortzen direnez, baliabide fosil eta ez-berriztagarri horren mende daude; hain zuzen ere, munduan ateratzen den petrolio guztitik $\% 5$ plastiko-industriara bideratzen da. Bestalde, mineral fosil horren prezioa ez da batere egonkorra, eta, aurreikuspenen arabera, egungo kontsumo-erritmoan 50 urte barru agortu egingo litzake [2].

Faktore horiek bioplastikoen igoera eragin dute, eta mundu-mailan ingurumen- eta politika-arloko eskakizunak material jasangarrien inguruko ikerkuntza ari dira bultzatzen, petroliotik eratorritako ohizko plastikoak ordezkatzeko helburuarekin. Hain zuzen ere, petroliotik eratorritako polimeroak arazo larriak eragiten ari dira ingurumenean birziklatzeko orduan erakusten duten konplexutasunaren ondorioz, ez baitira biodegradagarriak ezta konpostagarriak ere.

Plastiko bat bioplastiko izateko, bi baldintza kontuan hartzen dira: haren jatorria baliabide naturala izatea eta biodegradagarria izatea; konkretuki, talde horren barruan, baldintza biak betetzen dituztenak nabarmentzen dira [3]. Adibide moduan, artoa, soja, azukre-kana edo egurra baliabide natural eta berriztagarriak dira, prezio egonkorrak dituzte, eta, oro har, biosfera osoan zehar eskuratu daitezke; arrazoi horiengatik, baliabide interesgarriak dira materialak garatzeko eta petrolioaren transformazioan oinarritutako materialak ordezkatzeko aukera bezala.

Testuinguru honetan, baliabide natural edo biologikoetatik sintetizatutako polimeroak gailentzen dira polimero biodegradagarriak lortzeko, kontsumo energetikoa murrizteko asmoarekin. Tamalez, gaur egun material horiek lortzeko eta produzitzeko teknikak ez dira oraindik industrialki lehiakorrak, ohizko prozesu petrokimikoekin parekatzen baditugu. Lehiakortasun industrialera hurbiltzen den prozesu bakarra papergintzan da, baliabide berriztagarrietan oinarritutako produktuak eskala industrialean arrakastarekin garatu ditzakeen sektore bakarretakoa baita. Horren harira, papera produzitzeko teknikak plataforma bideragarritzat har daitezke polimero biodegradagarriekin produktu berriak garatzeko orduan. 
Horrela, polimero biodegradagarrien artean, biopolimeroak garapen betean daude, plastiko konbentzionalek ingurumenarentzat suposatzen duten arazoa eragozteko helburuarekin. Modu horretan, polimero naturaletan oinarritutako alternatibak garatu dira azken urteetan, polimero konbentzionalen propietateak eta funtzionalitateak mantentzeko nahian. Polimero natural horiek hainbat arlotan erabiltzen dira: enbalatze-industrian eta etxeko enbalatzeetan, plastikozko poltsetan, sukaldaritzan, medikuntzan, nekazaritza-produktuetan edo eta hortikulturan.

Polimero biodegradagarriei erabilera-denboran propietateak mantentzea eskatzen zaie, eta, epea bukatu ondoren, estruktura kimikoa aldatuz, ingurumenarekiko bateragarriak diren osagaitan deskonposatzea.

Gehienetan, biodegradazioz deskonposatzen dira; eragile biologikoek (entzimek, bakterioek edo mikroorganismoek) eragiten duten degradazioprozesu kimikoa da. Produktu baten degradazioa, ingurumenaren eraginpean, mikroorganismoen inplikazioaren bidez gertatzen da; prozesuaren ondorioz, pisu molekularra txikitzen da eta polimeroa puska organiko sinpletan degradatzen da.

Jatorri naturala duten polimero biodegradagarriak, 3 kategoriatan sailka daitezke [4] (ikusi 1. irudia):

a) Zuzenean biomasatik lortzen diren polimeroak. Kategoria honen adibide dira almidoia, kitina , zelulosa eta gisakoa polisakaridoak , kolagenoa, keratina edo zeta moduko proteinak.

Almidoia aplikazio handieneko termoplastiko biodegradagarria; honen izaera hidrofiliko handiari, kostu baxuari eta ugaritasunari esker, gehigarri biodegradagarri gisa erabili daiteke, edo, plastiko tradizionaletan, ordezkatze-material moduan. Konposatu horrek polimero sintetikoen kateen degradazioa edo frakmentazioa bizkortzen ditu, eta mikrobio-akzioak, bere aldetik, almidoia kontsumitzen du, polimeroan poroak sorraraziz eta materialaren desegitea eraginez.

Zelulosaz gain, material organiko ohizkoenetan kitina bigarrena da; itsas krustazeoetatik eta intsektuetatik ateratzen den polimero naturala. Beste adibide bat lignina da, material ugaria hau ere; landareen eta zenbait zelularen hormetatik ateratzen den kate aromatiko konplexuz (ez-hidrokarbonatuak) osatutako polimeroa da.

b) Baliabide naturaletatik ateratako monomeroen sintesi kimiko bidez produzitutako polimeroak. Mota honen adibide aipagarriena poliazido laktikoa da (PLA) da [15]. azido 2-hidroxi-propioniko edo azido laktiko monomeroaren polimerizazio kontrolatutik sintetizatzen da PLA. Monomeroa, bestalde, artoak, gariak edo azukretan aberats diren beste produktu batzuek gordetzen duten karbohidrato sinpleen fermentazio bidez sintetiza daiteke. PLA polimeroa bilakatzen ari da, bereziki, poliestireno (PS) edo polietilentereftalatoa 
(PET) moduko ohizko plastikoen alternatiba aparta. Polimero horren ezaugarri nabarmenenak atxikitako biodegradagarritasun-ahalmena, erresistentzia mekaniko handia eta prozesatzeko erraztasuna dira.

Talde honekin lotuak, badaude abian azido sukzinikoen eta gantz azidoen deribatuen inguruko ikerketak.

c) Bakterioen edo mikroorganismoen bidez lortutako polimeroak. Polimero horien artean polihidroxialkanatoak (PHAk) edo nanozelulosa bakterianoa nabarmendu daitezke. PHAk jatorri mikrobianoa duen eta pseudomona aeruginosaren bitartez lortutako poliester lineala da [5]. Polimero horrek polipropilenoaren (PP) antzeko propietateak ditu, eta puztearen eta moldaketaren bitartez lortzen da. Polimero honen desabantaila nagusia garestia dela da.

Bigarren adibidea, nanozelulosa bakterianoa, nahiko berria eta oparoa da; bakterioek eragindako biosintesiaren bidez produzitzen den polimeroa da, aurrerago azalduko den bezala.

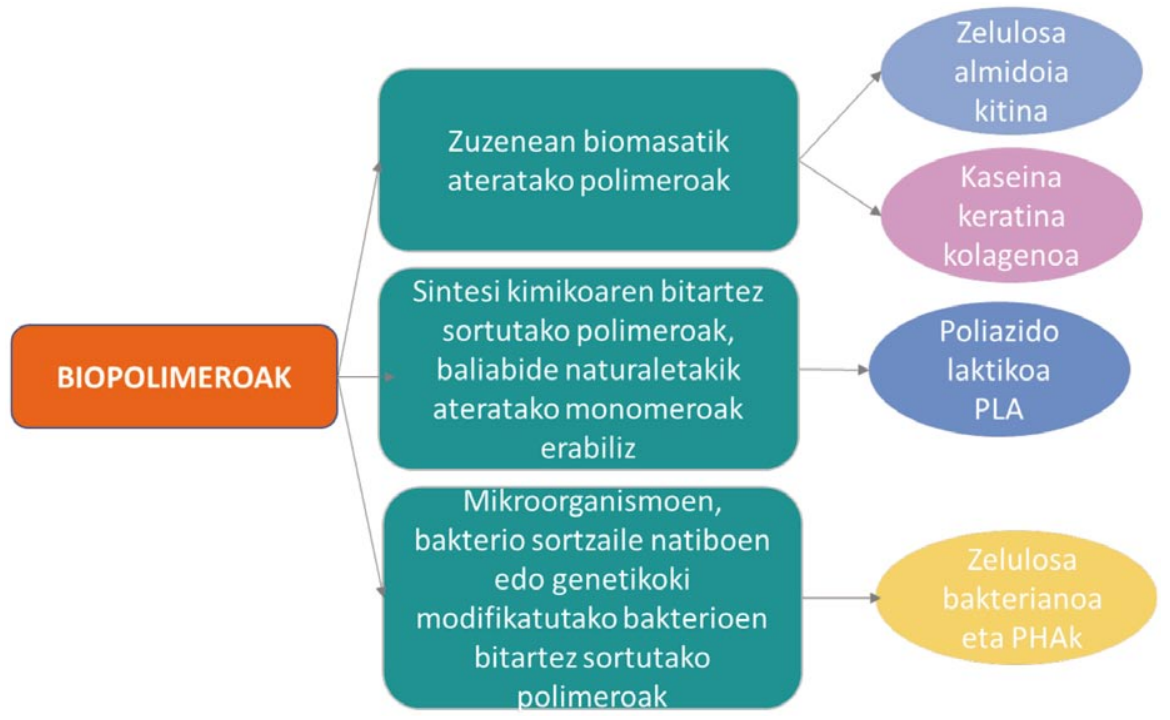

1. irudia. Biopolimeroen sailkapen orokorra eta adibideak.

Irudian sailkatutako polimeroak biopolimeroak dira, bi baldintza betetzen dituztelako: jatorri naturala izatea eta biodegradagarritasuna. Hauez gain, badira biodegradagarriak diren baina jatorri sintetikoa duten polimeroak; horien adibide dira polikaprolaktona eta zenbait poliester.

Atal honetan aipatutako biopolimeroak oso ugariak dira naturan, polimero ez-organikoetan gehitzeko aproposak dira, eta, prezio baxuez gain, 
biodegradagarri- eta biobateragarritasun-propietate apartak dituzte, eta, horiengatik biopolimero guztien artean zelulosari atzematen zaio etorkizun oparoena [10].

Bereziki fabrikazioan hobekuntzak lortu ahala, gero eta nabarmenago agertuko da material hori baliabide berriztagarriez guztiz edo partzialki osatutako eguneroko produktuetan.

\section{ZELULOSAN OINARRITUTAKO NANOMATERIALAK}

Aurretik aipatu den bezala, zelulosak ezaugarri apartak ditu eta naturan aurkitu daitekeen polimero natural oparoena da. Bestalde, ezin daiteke elikagai bezala erabili, eta, horren ondorioz, ez dago, almidoiarekin gertatzen den bezala, etikaren inguruko arazorik, eta hori ere abantaila bat da. Zelulosa landareetan aurkitu daiteke; horien oinarrizko zelulen hormen egituraren osagai garrantzitsuena da. Erakusten dituen propietate nabarmenenak honako hauek dira:

- Propietate mekaniko paregabeak: zurruntasun eta modulu elastiko altuak, nahiz eta zelulosaren jatorriaren arabera aldakorra izan. Propietate horiek nanozuntz elementaletan oinarrituta dauden zuntz naturalen egitura hierarkikoaren ondorio dira.

- Izaera hidrofilikoa.

- Uretan ez-disolbagarria.

- Berriztagarritasuna.

- Toxikotasunik eza.

- Biodegradagarritasuna: degradazio entzimatikoaren bidez zelulosa zelobiosa bihurtzen da, eta honen degradazioaren bitartez, glukosa eta energia lortzen dira.

Egitura kimikoari dagokionez (ikusi 2. irudia), $\beta$-D-glukosa (glukopiranosa) 1-4 loturen bitartez osatutako zelobiosa-unitateen errepikapenaren bitartez osatutako polimero bat da zelulosa. Lerro-formako kateak sortzen dira eta kate horiek elkarren arteko hidrogeno-zubien bitartez elkarri eragiten diote, eta zuntzak eta sareak osatzen dira. Nahiz eta zelulosa natiboaren polimerizazio-gradua esperimentalki kalkulatzea konplexua den, 10.000 tik gertu dagoela esan daiteke, eta hori $3,2 \times 10^{6} \mathrm{~g} / \mathrm{mol}$ inguruko pisu molekularra da.

Zelulosa-mikrozuntzek zurruntasunarekiko, ez-disolbagarritasunarekiko eta eraso entzimatikoekiko erresistentzia-ezaugarriak agertzen dituzte, alde kristalinoak dituzte, eta alde ez-ordenatu eta amorfoak, propietate mekaniko txarragoak dituztenak. Zelulosaren aplikazioen artean nabarmenena eta ezagunena papergintza da; hala ere, ehungintzako eta elikagaigintzako eta kosmetika-industrietako osagaia ere bada. 


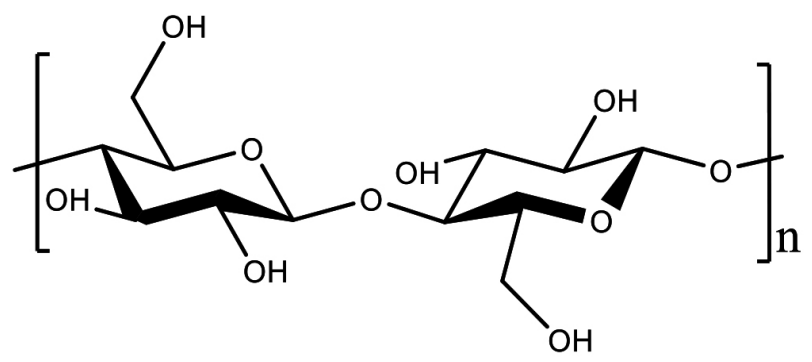

2. irudia. Zelulosaren egitura kimikoa.

\subsection{Nanozelulosa eta nanozelulosaren deribatuak}

Aurreko atalean aipatu den bezala, zelulosa material interesgarria da eta aski ezaguna; hala ere, ikerketa arloan, nanomaterialak ari dira interes handia eragiten. Zelulosari dagokionez, zelulosaren nanoestrukturak dira interes handia sortzen ari direnak, haien ezaugarri berezien ondorioz.

Eskala nanometrikoko materialen inguruan piztu da interesa, hain zuzen ere material horiek neurri txiki horretan agertzen dituzten propietate fisiko-kimikoen ondorioz. Horrela, atomo eta molekulen eskalako materialak sakonki aztertzen eta garatzen ari dira horien ezaugarri berezien eta propietateen suspertzean duten eraginagatik. Nanoeskala horretako materialek gainazal espezifiko altua dute (itxura-erlazio handiaren ondorioz) eta ezaugarri horrek eragin garrantzitsua dauka aipatutako propietate berezietan. Testuinguru honetan, nanozelulosa da naturalki lor daitekeen nanomaterial interesgarrienetariko bat; besteak beste, haren multifuntzionaltasun-aukerengatik [8]. Bestalde, nanozelulosak baditu ezohiko propietate batzuk bera beste material batzuetatik bereizten dutenak:

- Morfologia bereziak (ikusi 3. irudia).

- Neurri nanometrikoak eta nanozelulosa-motaren arabera aldakorrak.

- Azalera espezifiko handia: $10 \mathrm{~m}^{2} / \mathrm{g}$ eta $1.000 \mathrm{~m}^{2} / \mathrm{g}$ artekoa.

- Berezko berritze eta biodegradagarritasuna.

- Dentsitate baxua: $1,4 \mathrm{~g} / \mathrm{cm}^{3}$ eta $1,6 \mathrm{~g} / \mathrm{cm}^{3}$ artekoa

- Gardentasun optikoa: \% 80 inguruko transmitantzia.

- Zurruntasun eta tentsio-erresistentzia handiak.

- Malgutasun-modulu handia (Young modulua): $150 \mathrm{GPa}$.

- Egonkortasun termikoa $\approx 200{ }^{\circ} \mathrm{C}$ eta espantsio termikoaren koefiziente txikia: $3 \mathrm{ppm} /{ }^{\circ} \mathrm{C}$ eta $22 \mathrm{ppm} /{ }^{\circ} \mathrm{C}$ artekoa.

- Azal-erreaktibotasun kimikoa, egokitze-aukera ugariek kontrolatutako interakzioen bitartez (beste polimeroekin, nanopartikulekin, molekula txikiekin edo material biologikoekin).

- Kristalinitate altua (batez ere zelulosa nanokristalek). 
- Kristal likidoaren portaera.

- Hesi-propietateak, gasen aurkako irazgaiztasuna.

- Biobateragarritasuna eta toxikotasunik eza.

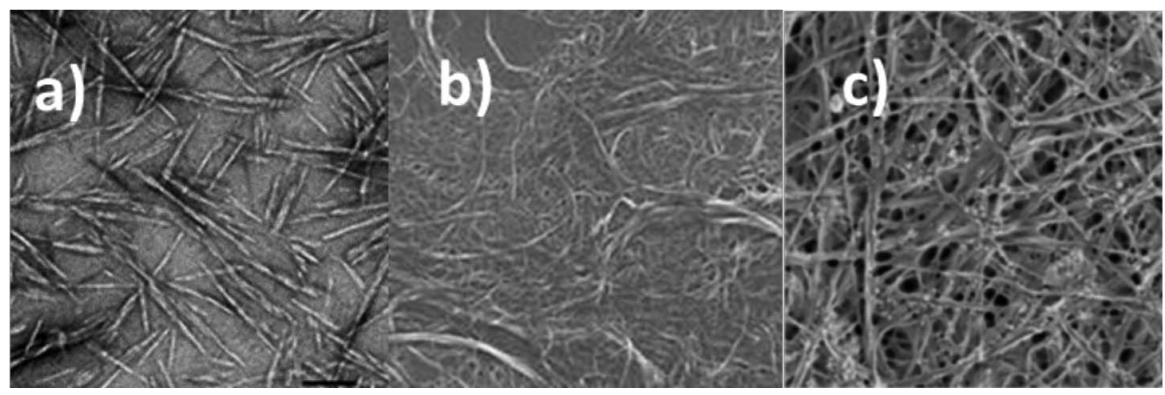

3. irudia. Nanozelulosaren deribatuak a) ZNK b) ZNZ c) NZB [13-14].

Ezan bezala, nanozelulosa baliabide natural desberdinetatik lor daiteke. Ezagunenak landareak dira, baina ez bakarrak; izan ere, egitura eta mota desberdinetan lor daiteke nanozelulosa, teknika edo prozesu desberdinak erabiliz [12]:

1. biosintesi bidez,

2. landareen desintegrazioaren bidez: prozesu mekanikoak eta aurretratamenduak erabiliz zuntzak eta nanozuntzak lortzen dira; ondoren, hidrolisi kimikoa eraginez, alde amorfoak desegiten eta alde kristalinoak mantentzen dira (ikusi 4. irudia).

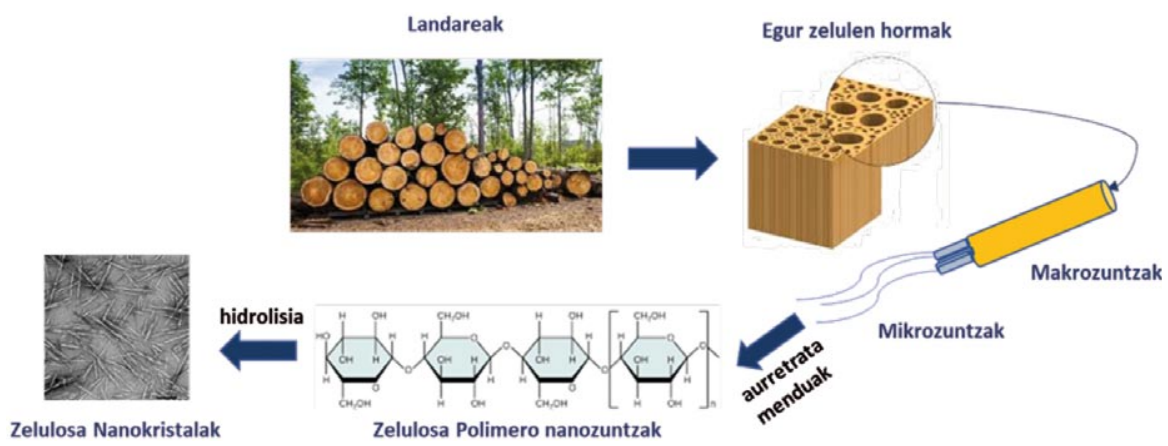

4. irudia. Zelulosa-nanokristalen lorpen prozesua.

Aipatutako sintesi- moduek 3 nanozelulosa mota desberdinetara daramate: 


\subsection{Zelulosa-nanokristalak edo ZNKak}

Zelulosa-nanokristalak (ZNKak), zelulosa nanokristalino izenez ere ezagunak, besteak beste egur-pulpetan edo kotoi landareetan aurkitu daitekeen zelulosa naturaletik ateratzen dira. Behin prozesu mekanikoen eta aurretratamenduen bidez zelulosa mikrokristalinoa lortuta, hidrolisi azidoaren bitartez zelulosa-nanokristalak lortzen dira. Nanokristal horiek, hidrolisiprozesuan ohikoa den azido sulfurikoaren eraginez, sulfato taldeekin negatiboki kargatuta geratzen dira, eta horrek eragin handia du material honen erreaktibotasunean. Honako hauek dira, orokorrean, zelulosa-nanokristalen ezaugarri nabarmenenak $[8-10,16]$ :

- Sintesi-metodoa: prozesu kimikoa (hidrolisi-azidoa), alde amorfoak desegiteko eta alde kristalinoak mantendu eta nanokristalak lortzeko (ikusi 4. irudia).

- Morfologia-egitura: hagatxo moduko nanopartikulak; hagatxo bakoitza kristal zurrun bakar bat bezalakoa da.

- Partikulen neurriak: $5 \mathrm{~nm}$ eta $50 \mathrm{~nm}$ arteko zehar-sekzioa eta $50 \mathrm{~nm}$ eta $500 \mathrm{~nm}$ arteko luzera.

- Kristalinitatea: \% 88 ingurukoa.

- Transmitantzia optikoa.

- Dentsitate baxua: $1,5 \mathrm{~g} / \mathrm{cm}^{3}$ eta $1,6 \mathrm{~g} / \mathrm{cm}^{3}$ artekoa.

- Gainazal handia $50 \mathrm{~m}^{2} / \mathrm{g}$ eta $70 \mathrm{~m}^{2} / \mathrm{g}$ artekoa.

- Zurruntasun eta erresistentzia mekaniko nabarmena, Young Modulu handiekin (130 GPa).

- Ur koloide egonkorra osatzeko eta ura biltzeko ahalmen handia.

- Gainazala-aldaketa kimiko erraza, erreaktibitatea.

Propietate berezi hauei esker ZNKa material egokia bihurtzen da polimero matrizeak indartzeko, barneratzen diren polimero horien propietate mekaniko, termiko eta optikoak edo hesi-propietateak hobetzeko.

Tamalez, ZNKak zenbait desabantaila ere baditu bere egitura kimikoaren ondorioz. Desabantaila horien artean, termoplastizitate falta, ura xurgatzeko erraztasuna edota disolbagarritasun txikia dira aipagarrienak. Bestalde, nanokonpositeen inguruan gaur egun dagoen erronkarik handienetakoa da nanorrefortzuak matrizeen barneko dispertsio ona lortzea. NKen propietateek malgutasun handia eskaintzen dute behetik gorako hurbilketaz fabrikatutako gailu funtzionalentzat. Hain zuzen ere, ZNKak funtzionalizatzeko, horien gainazala kationizazioaren, silizazioaren edo grafting polimeroaren bitartez eralda daiteke; modu horiek aukera erabilienak dira, baina ez bakarrak. 


\subsection{Zelulosa-nanozuntzak (ZNZ) edo nanofibrilatutako zelulosa (NFZ)}

Zelulosa-nanozuntzak (ZNZak) edo zelulosa nanofibrilatua lortzeko lehen pausoa zuntzak egurraren pulpatik, kotoi-landaretik, paper birziklatutik edo gisako materialetatik ateratzea da. Lehen zuntz horiek findu eta homogeneizatu egiten dira mikrofibrilatutako zelulosa lortzeko. Horretatik aurrera, mikrofibrilatutako zelulosari prozesu kimiko eta mekanikoa ezartzen zaio isolatutako nanozuntzak lortzeko.

Aurretratamenduetarako garatutako teknika gehienak prozesu kimikoetan oinarritzen dira; prozesu erabilienak 2,2,6,6-Tetramethylpiperidine 1-oxyl (TEMPO) bidez katalizatutako oxidazioa, klorito-periodato bitarteko karboximetilazioa, sulfonazioa edo hidrolisi azidoa dira. Kontuan izan behar da aurretratamendu horiek sintesi-prozesuan produktu kimiko ez-jasangarriak eta kostu altuagoak dakarrela; beraz, beste teknika batzuk interesgarriagoak izan daitezke. Teknika horien artean hidrolisi entzimatikoa eta aurretratamendu mekanikoak daude; nahiz eta orain arte lortutako propietateak kaskarragoak izan, aukera jasankorragoak dira bai ekonomiaren ikus puntutik, bai ingurumenaren aldetik. Beraz, zelulosa-nanozuntzen deskribapen eta ezaugarri nagusiak honako hauek dira [13-18]:

- Sintesi-metodoa: Presio handiko homogeneizazioaren eta ehoketaren ondoren, aurretratamendu kimikoa edo entzimatikoa erabiltzen da nanozuntzak isolatzeko, edo prozesu mekaniko erabil daiteke delaminazioa lortzeko eta zuntzetatik nanozuntzak lortzeko.

- Morfologia-egitura: Zelulosa-nanozuntz bakar edo agregatuak, luzeak eta malguak, alde kristalino eta amorfodunak.

- Partikula neurriak: 5 eta $50 \mathrm{~nm}$ inguruko diametroa eta zenbait $\mu \mathrm{m}$-ko luzera, izpitze prozesuaren eta aurretratamenduen arabera.

- Trakzio-erresistentzia eta malgutasun handia, $100 \mathrm{GPa}$ inguruko Young Moduluarekin.

- Kristalinitatea: \% 70 ingurukoa.

- Fisikoki korapilatutako sareak oso kontzentrazio baxuetan $(<\% 1$ pisuan).

Zelulosa-nanozuntzak eta haren deribatuak zabalki erabili izan dira partikula inorganikoentzako txantiloi bezala, eta nanozuntzen malgutasun handiari eta neurri bereziei esker, zelulosa-nanozuntz/nanopartikula inorganikodun konpositeak hainbat industria-aplikaziotarako erabiltzen dira: papergintza, mintzak, ehun-gaiak eta abar. Dena dela, zenbait aplikaziotarako, zuntzen luzerak mugak ezartzen ditu nanoeskalakoa ez bada. 


\subsection{Nanozelulosa bakterianoa (NZB)}

Nanozelulosa bakterianoa, zelulosa mikrobianoa izenez ere ezaguna, zenbait bakteriok eragindako biosintesi bidez produzitzen da. Nanozelulosa bakterianoaren ezaugarriak bakterio motaren eta hazkuntza-baldintzen arabera aldatuko dira, baina gehienetan kristalinitate altuko zelulosa-nanozuntzezko sare korapilatu baten forma hartzen du, hidrogeno-loturez batuta zuntzak gurutzatzen diren tokietan [12].

Adibidez, hazkuntza likido estatikoan eragiten denean, Gluconacetobacter xylinus, Gluconacetobacter medellinensis edo beste zelulosa mota bat produzitzeko espezie-kultibo garbien bitartez, gel uniforme bat sortzen da, haren $\% 1$ zelulosa-zuntzei dagokie eta \% 99 likidoa da, aire-inguru interfasean dagoena. Orokorrean, honako hauek dira nanozelulosa bakterianoaren ezaugarriak:

- Sintesi-metodoak: bakterioek (Acerobacte xylinum) eragindako biosintesiaren bitartez; unitate txikietatik ( $\AA$ ) unitate txikiko (nm) nanozelulosa lortzen da; edo glukosa-kateak bakterio-gorputzaren barnean sortuz; behin lortuta, zelulosa bakterioaren zelulen bilgarriaren poro txikietatik kanporatzen da.

- Morfologia-egitura: glukosa-kateen konbinazioarekin mikrozuntzek lazo-itxurako agregatu bat osatzen dute, eta beste zelulosa-zuntzekin sare-itxurako egitura bat sortzen dute.

- Partikula neurriak: $5 \mathrm{~nm}$ eta $100 \mathrm{~nm}$ inguruko diametroa eta askotan $2 \mu \mathrm{m}$ baino luzeagoak.

- Egonkortasun mekanikoa eta malgutasuna; 150 GPa-eko Young Moduluak lortzen dira.

- Kristalinitatea (\% 72-91).

- Porotasun oso handia.

- Gainazalaren modifikazio kimikorako erraztasuna.

Nanozelulosa bakterianoaren zuntzen egitura-ezaugarriak bitarteko direla (porositate altua, gainazala kimikoki eraldatzeko erraztasuna, eta gainazalak hidrogel-forman dituen egonkortasun mekanikoa eta malgutasuna), NZB gelak asko erabiltzen dira medikuntzan, elektronikan eta ehungintzan moduko arloetan [14].

\section{NANOZELULOSAN OINARRITUTAKO NANOKOMPOSITEAK}

Nanozelulosaren funtzionalizazio-aukera ugariek eragin handia dute propietate berri eta pertsonalizatutako materialaren garapenean; bereziki, nanozelulosan oinarritutako nanokonpositeen garapenean. Nanozelulosaren gainazalak funtzionalizazio-aukera ugari eskaintzen ditu, nanoeskalako di- 
mentsioak eragindako hainbat eta hainbat azaleko $-\mathrm{OH}$ talderen eta gainazal espezifiko handiaren ondorioz. Gainazal-funtzionalizaziorako prozesu esperimental gehienak kondizio epeletan egiten dira nanopartikulen integritatea eta eraldatutako gainazal- kateak peeling efektutik babesteko.

Funtzionalizatutako nanozelulosa polaritate baxuko likidoetan ere dispertsa daiteke, eta matrize soluzioekin nahasi. Horrek inguru ez-polarretan nanozelulosaren dispertsioaren hobetzea ahalbidetzen du eta nanozelulosaren azken aplikazioaren optimizazioa erraztu. Hala ere, horren ondorioz, hidrogeno-loturen bitartezko nanozelulosa partikulen interakzioak murrizten dira, eta murrizketa hori da nanozelulosaren dispertsio onaren arrazoia [18-19]. Beraz, nanozelulosaren propietate fisiko eta kimikoek baliagarri egiten dute hainbat konposite matrize hidrofiliko edo hidrofobikoetan erabiltzeko, eta bai material hibridoetan erabiltzeko ere. Gainera, nanozelulosaren gainazal espezifiko handiak barne interakzioak egiten ditu posible, baita beste polimero batzuekin, beste nanopartikulekin edo molekula txikiekin loturak sortzea ere.

Gaur egun materialak modu desberdinetan sailka daitezke, gehienetan aplikazioaren arabera edo jatorriaren arabera, baina sailkapen horiek ez dituzte material mota guztiak kontuan hartzen. Horregatik, eta aipatutako sailkapenak murriztuak direlako, askotan, aukera erabilgarria da oinarrizko egituraren distribuzioaren arabera sailkatzea edo, beste modu batera esanda, egituran duten bolumen aske kopuruaren arabera. Sailkapen horretan, porodun edo poro gabeko materialak aurkitu daitezke. Hain zuzen ere, ezaugarri horrek, egituran bolumen aske handia edo txikia izateak, diferentzia nabarmenak eragiten ditu materialen ezaugarri fisikoetan eta portaeran.

Azaldutako sailkapen aukeraren arabera, nanozelulosaren estruktura nabarmenenak aipatuko dira:

\subsection{Gelak}

Gela material solido gelatinakara da, eta haren propietateak itxura leun eta bigun batetik itxura gogor eta zurrunera alda daitezke (ikusi 5. irudia) [11]. Egoera geldikorrean jariakortasunik eza duen material solido gelatinakara gisa ere defini daiteke. Bere sare tridimentsionalari esker, solido bezala portatzen da, nahiz eta barnean likidoa duen eta gel-estruktura mugatzen duen solidoa izan. Beste era batera esanda, gela solido baten barneko molekula likidoen estalgarria da; solidoa fase jarraitua da, eta likidoa fase sakabanatua. Barneko likido hori ura denean, hidrogel deitzen zaio, eta gel bateko partikula solidoen diametroa $1 \mathrm{~nm}$ eta $1.000 \mathrm{~nm}$ bitartekoa izan daiteke.

Gel mota desberdinak aurki daitezke, gela osatzen duen konposatu organiko edo ez-organikoaren jatorriaren arabera, konposatuak zehazten baitu zein izango den erabileraren azken xedea. 
Orain dela gutxi arte gel erabilienak eta ikertuenak silizezko gela eta aluminazkoa izan dira, baina azken urteetan nanozelulosa-gelak oso ezagunak egin dira.

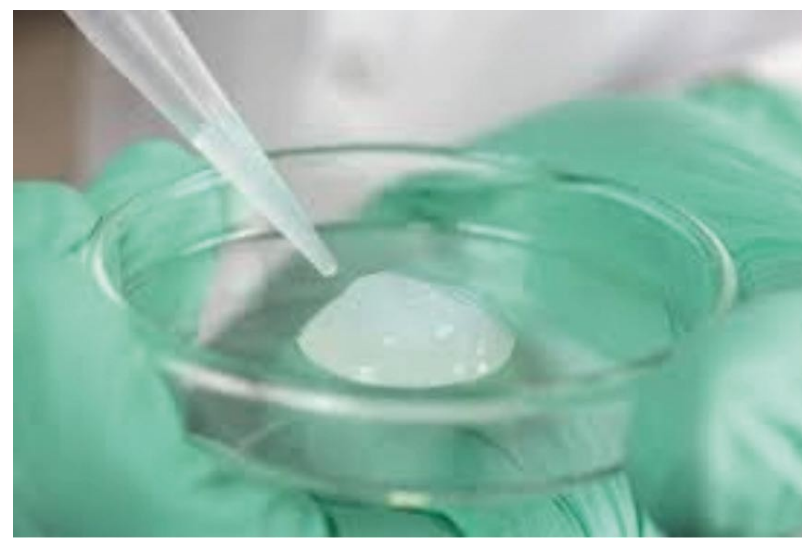

5. irudia. Nanozelulosa hidrogela.

Hidrogela lortzeko, nanozelulosaren suspentsioaren egoerak aldatu behar dira gainazaleko taldeak estaliz (gatzak gehituz), gainazala eraldatuz (dela kationizazioz, dela silanizazioz), edo beste polimero batekin lotuz [20]. Horrela, kateen arteko indar elektroestatikoak txikiagotzen dira, egonkortasun koloidala handitzen da, eta, ondorioz, gela osatzeko aukera handitzen da.

\subsection{Aerogelak}

Aerogelak material bereziak dira: oso arinak eta porotasun handikoak (\% 90-99,8); dentsitate izugarri txikia dute, eta gainazal oso handia, $100 \mathrm{~cm}^{2} / \mathrm{g}$ eta $600 \mathrm{~cm}^{2} / \mathrm{g}$ artekoa (ikusi 6 .irudia). Aerogel ezagunenak silize, ikatz edo polimero sintetikoetan daude oinarrituta, baina azkenaldian material berriztagarri eta jasankorretan oinarritutako aerogelak oso arrakastatsuak ari dira bilakatzen. Horien artean, nanozelulosa-aerogelek ezaugarri berriak agertzen dituzte: eroankortasun termiko txikia, malgutasuna, isolatzaile termiko ona, bustitako erresilientzia nabarmena eta soinu-absortzioa. Zelulosa-aerogelak, normalki zenbait urratsetako sol-gel prozesuen bidez lortzen dira. Lehen pausoa zelulosaren disoluzioa da; ondoren, gela lortu eta disolbatzaile-aldaketa egiten da; azkenik, lehortze superkritikoaren edo liofilizazio-prozesuaren bitartez aerogela edo xerogela lortzen da [21, 38].

Behin gela lortuta, material porodunak lortzeko moduaren arabera, aerogelak ez ezik, kriogelak ere lor ditzakegu. 


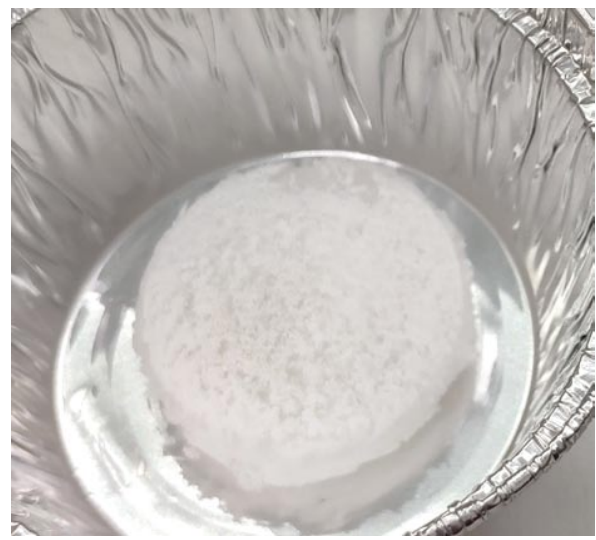

6. irudia. Nanozelulosa-aerogela.

Kriogela material makroporoduna da; azkenaldian nahiko ikertu da banaketa- eta purifikazio-prozesuetan erabiltzeko. Kriogelaren sorreran, poroen tamaina kontrolatzeko, disolbatzailearen kristalizazioa kontuan izan behar da. Beraz, kriogela nola lortzen den, poro- mikroegiturak edo porosare desberdinak lortzen dira. Hain zuzen ere, kristalizazio baldintza one$\tan , \% 75$ eta $\% 90$ arteko porositatea lor daiteke.

\subsection{Mintzak}

Nanozelulosa-mintzek paper-itxura daukate, eta lodiera eta poro-tamaina aldakorra, nanozelulosa-kontzentrazioaren (\% pisuan) kantitatearen eta lorpen-prosezuaren arabera (ikusi 7. irudia). Nanozelulosa-mintzek Young modulu handia dute, $14 \mathrm{GPa}$ ingurukoa, eta dentsitate txikia, nahiz eta aerogelarenak $\left(0,008-0,05 \mathrm{~g} / \mathrm{cm}^{3}\right)$ baino askoz handiagoa $(1,4-$ $\left.1,6 \mathrm{~g} / \mathrm{cm}^{3}\right)[16,21]$.

Mintzak lortzeko teknika desberdinak daude. Adibide bat dispertsio-lurruntzearen metodoa da. Mintza lortzeko, ur-nanozelulosa dispertsioa, ondo nahasi ondoren, Petri plater batean isurtzen da, tenperatura egokian, ura lurrundu eta mintz lehorra lortu arte. Zelulosa mintzak hot pressing bitartez ere lor daitezke, prentsa batean zelulosa solidoa sartu eta tenperatura egokian zapaldu eta luzarazi ondoren.

Nanozelulosaren erreaktibitate eta funtzionalizazioari esker, material honetan oinarritutako nanokonposite-aukera asko sintetiza daitezke talde kimiko desberdinak gehituz, aplikazio desberdinetarako. Aplikazio horien artean, enbalatzeko film moduko erabilera da ezagunena, ohiko plastiko ezbiodegradagarriak ordezko gisa, baina medikuntzan eta beste arlo batzuetan ere ari dira nanozelulos-mintzentzat aplikazioa berriak agertzen [7, 16-17]. 


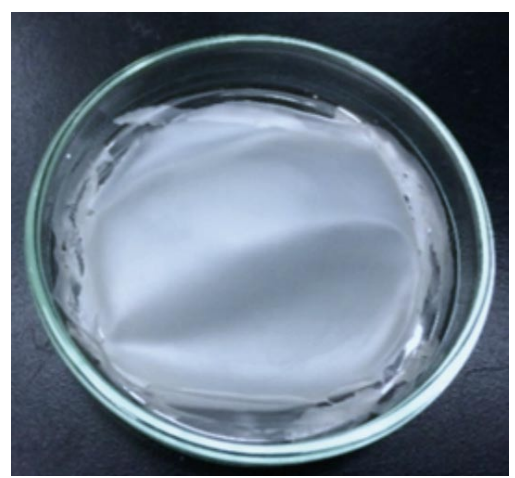

7. irudia. Nanozelulosa mintza.

\section{APLIKAZIOAK}

Nanozelulosa funtzionalizatuak, birsor daitezkeen material desberdin (likido, solido, gel) eta egonkorren inguruan, aukera zabalak ematen ditu aplikazio esparru handi baterako. Material horren propietate bereziak kontuan hartuta, nanozelulosan oinarritutako material konposatuak erabilera anitzetarako potentziala erakusten ari dira hainbat aplikazio-arlotan [24] (ikusi 9. irudia). Hain zuzen ere, atal honetan, nanozelulosaren eta nanozelulosatik deribatutako materialen aplikazio-aukerak sailkatu eta deskribatuko dira sektore eta arlo desberdinen arabera.

\subsection{Ingurumena eta Energia}

Ingurumenarekin eta energiarekin edo energia-efizientziarekin lotutako aktibitate askotan, nanozelulosak eta haren deribatuek aplikazio potentzialak dituzte. Aplikazio horietatik ezagunenak aipatuko dira.

\subsubsection{Iragazkia ur-hondakinen tratamenduetan}

Industria mota desberdinek eragindako ur-hondakinek, normalki, esekidura solidoak, partikula organiko edo inorganikoak, metalak eta beste ezpurutasun batzuk edukitzen dituzte. Partikula horien tamaina txikia eta gainazal-kargaren presentzia direla eta, erronka bihurtzen da partikula horiek masa handienetik gertu kokatzea eta iragaztea.

Partikula eta konposatu horiek erauzteko modu desberdinak daude: hauspeatze kimikoa, mintz bidezko separazioa, ioi-trukea, flokulazioa, elektrolisia eta baporizazioa. Zentzu horretan, nanozelulosa ur industrialetan edo ur-hondarretatik kutsatzaile organiko edo ez-organikoak ezaba- 
tzeko erabil daiteke. Bere barne-egitura bereziari esker funtzionalizatutako nanozelulosaren zenbait taldek ioi metalikoak harrapatzeko ahalmena dute, gero uretatik ateratzeko [25].

Teknika batzuk amina eta karboxilato taldeetan oinarrituta daude gelazio eragile bezala edota nanozelulosaren $-\mathrm{OH}$ taldeen oxidazio katalitiko eta selektiboaren bitartez. Sukzinilazio-erreakzioa ere beste funtzionalizazio-aukera bat da. Ondorioz, funtzionalizatutako nanozelulosa berriki erabilia izan da ur-hondakinen koagulazio-flokulazio tratamenduetan. Koagulazio-flokulazio tratamendu konbinatuak suspentsio egonkor baten uhertasun-hondarraren oxigeno-eskaera kimiko (OEK) txikiagoa eragiten du, eta, horrekin batera, kontsumo kimikoaren jaitsiera nabarmena.

\subsubsection{Xurgatzailea eta bereizlea ur kaltetuetan}

Petrolioz edo olioz kutsatutako urek eragin tamalgarria dute uretako eta lurzoruetako izaki bizidunengan, eta baita gizakien osasun eta ekonomian ere. Besteak beste, turismoa mehatxupean jartzen dute, material horien geruza-propietate, zatarkeria eta usain nazkagarriarengatik. Horregatik, mundu mailan premiazko eskaria dago uretako petrolio-kutsadurak ezabatzeko teknologia eta modu desberdinak garatzearen inguruan.

Xurgatzaile bezala erabiltzen diren materialen inguruan ere kezka dago, eta jasangarritasuna, kostu efektiboa, berrerabilera eta ingurumenarekiko lagungarri izatea dira material horien ezaugarri interesgarriak. Zentzu horretan, nanozelulosan oinarritutako materialek etorkizun handia dute haren neurri nanometrikoari esker $(2-100 \mathrm{~nm})$. Bestalde, berriki garatutako nanozelulosa-aerogel berrienek konbinatu egin dituzte hiru dimentsioko aerogel materialen porotasuna, gainazal handia eta dentsitate baxua, eta material naturalen propietate mekaniko ikusgarria, oparotasuna, berritze-ahalmen naturala, biodegradagarritasuna eta azalera-aldaketarako ahalmen handia. Hori guztia-kontuan hartuta, nanozelulosan oinarritutako aerogelak material jasangarri interesgarriak dira, olio-xurgatzaile bezala erabiltzeko duten xurgatzaile-ahalmen handia dela-eta; aplikazio horretarako, lehenik aerogela funtzionalizatu egin behar da propietate hidrofobikoak ezartzeko [26-27].

Ezaugarri hori bereziki, aproposa da ingurumeneko kalteen zuzenketan; adibidez, itsasoetako edo beste inguru batzuetako olioak ezabatzeko. Xurgatzaile-aplikaziorako ez ezik, nanozelulosa-aerogeletan oinarritutako mintzen inguruko garapena nabarmen ari da hazten ingurumenerako aplikazioetarako ere; besteak beste, likido desberdinak bereizteko porositate izugarriko material horiek duten ahalmenagatik. Azkenaldian, mintz-teknologiak, beste ohiko adsortzio-, destilatze- edo erauzte-teknologia batzuen aurrean, gailendu egin dira etorkizuneko teknologia moduan, haien berezko abantaila eta nagusitasunarengatik. Mintzak erregai-zeluletan, gas-hesietan edo ur-purifikaziorako aplikazioetan erabil daitezke, besteak beste [28]. 


\subsubsection{Energia-meta eta eguzki-zelulak}

Nanozelulosaren beste aplikazio arloa energia-metaketa da. Zentzu horretan, zelulosa-nanozuntzez osatutako foam edo aerogelek karbono dioxidoa harrapatu eta bakartu dezakete, gas- biltegi eta airea purifikatzeko iragazle gisa jarduten.

Bestalde, metaketa-sistemen (litio-baterien, superkondentsadoreen edo eguzki-zelulen) eskaria gero eta handiagoa da, eta, gainera, sistema horiek jasangarriak izatea eskatzen da; testuinguru horretan, nanozelulosaren garapenak eta erabilerak ere badituzte aukerak. Zehazki, nanozelulosa elektrodo bezala erabil daiteke sistema elektrokimikoetan, material horren propietate fisiko onak direla eta, baina aplikazio horretarako beharrezkoa da aurretik nanozelulosan aldaketa fisiko-kimikoak eta konduktibitate elektrikoa eragitea [29].

Energia-metaketan ez ezik, nanozelulosa energia fotovoltaikoaren oinarri diren eguzki-zelulen osagai moduan ere erabiltzen hasia da [39].

\subsection{Biomedikuntza}

\subsubsection{Substantzia kimikoen garraiobidea eta emailea}

Nanozelulosa funtzionalizatuaren aplikazio-arlo bat biomedikuntza da, eta arlo horren barruan, oso interesgarria da farmakoak dispentsatzeko izan dezakeen ahalmena. Hain zuzen ere, proteinak, entzimak edo peptidoak immobilizatzeko, garraiatzeko eta azkenik askatzeko ahalmena dauka nanozelulosaren gainazal eta porositate handiari esker [24, 30].

\subsubsection{Soluzio antiseptikoak}

Nanozelulosak mintz edo gel bilakatzeko duen ahalmenari (lehenago azaldua) propietate antimikrobianoak gehitzen badizkiogu, zeinak zilarrarekin $(\mathrm{Ag})$ funtzionalizatzeak ematen baitizkio, material aparta lor dezakegu tiritak eta beste soluzio antiseptiko malgu batzuk fabrikatzeko. Hain zuzen ere, zilarrak both E. coli eta S. aureus bakterioen hazkuntza inhibitzen duela hauteman da [31].

Beraz, zilar-partikula txikiekin funtzionalizatutako nanozelulosa-suspentsioak erabilgarri dira soluzio antiseptiko moduan edo tirita antiseptiko bezala erabiltzeko.

\subsubsection{Inplante-protesi eta scaffold biomedikoak}

Nanozelulosaren propietate bereziak direla eta, (horien artean propietate mekaniko onak) toxikotasunik ezari eta biobateragarritasunari esker, nanozelulosa material egokia da gorputz barnean sartzen diren protesi, in- 
plante eta ehunen osagai bezala erabiltzeko. Kasu batzuetan, nanozelulosa material estrukturala izan daiteke, eta beste batzuetan, zelulosa-nanokristal eta nanozuntzak; beste matrize batzuetan, errefortzu-material bezala sakabanatzen dira. Aplikazio horren adibide dira hortz-birsorkuntzan erabiltzen diren inplante eta ehun sintetikoak, edo 3D inpresio bitartez fabrikatu daitezkeen nanozelulosa-protesiak, edo birsorkuntzan eta zelula- hazkuntzan erabiltzen diren scaffold edo hiru dimentsioko estrukturak [32] (ikusi 8. irudia).

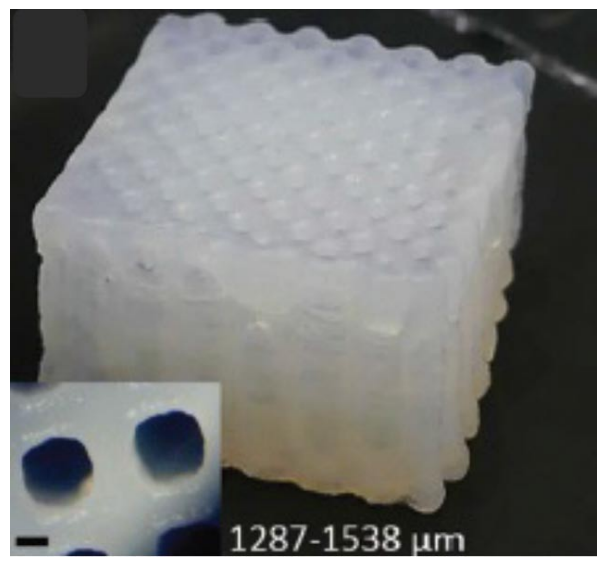

8. irudia. $3 \mathrm{D}$ inprimagailu bitartez fabrikatutako zelulosa-nanokristalezko estruktura tridimentsionala.

\subsection{Sentsorika eta Elektronika}

Nanozelulosaren azaleko talde funtzionalak molekula biologiko mota desberdinekin uztar daitezke, eta nanozelulosak nanopartikula inorganikoak bere gainazalean kokatzeko ere balio dezake. Ezaugarri horiei esker nanozelulosa biosentsoreetan erabil daiteke [22]. Hain zuzen ere, biosentsoreek informazio analitikoa erakusten dute arlo desberdinetarako: medikuntza- diagnostikoak, ingurumenaren monitorizazioa, elikagaien kalitatearen kontrola, sentsorika fisiko-kimikoa edo bioirudiak, besteak beste.

Adibidez, nanozelulosa funtzionalizatuarekin uztar daitezkeen biomolekulak azido nukleikoak dira. Horrek hibridazio itzulgarria ahalbidetzen du, eta nanozelulosak, azido nukleikoen molekulak detektatzeko duen gaitasuna bitarteko dela, tenperatura altuetan banantzen den duplex bat osa dezake. Bestalde, nanozelulosa bitartez funtzionalizatutako material inorganikoak azido nukleikoen hibridazioaren detekzio elektrikorako ere erabil daitezke. Nanozelulosa bitartez funtzionalizatutako titanio oxidoak $\left(\mathrm{TiO}_{2}\right)$ 
bide elektroi-eroale gisa erabil daitezke, hain zuzen ere metahemoglobina immobilizatzeko aproposa den nanozelulosa-egitura zabaldu samartu bat erabilita. Azkenik, nanozelulosa zitosinaren bidez funtzionalizaten badugu, surfaktanteak detektatzeko sentsibilitate eta potentzial nabarmena agertzen duen materiala lor daiteke. Aurreikus daiteke plataforma gisa nanozelulosa duten biosentsore moldakorretara pasatuko direla laster gaur egun plastiko-, beira- edo paper-plataformetan oinarritutako sentsore eta inprimatutako tresna elektroniko asko, sentsorika konbentzionala guztiz aldatuz [33-34].

\subsection{Material eta konposite berriak sektore desberdinetarako}

Gaur egun, nanozelulosadun materialak askotan aurkitu ditzakegu aplikazio eta sektore desberdinetan erabilita. Batzuetan, zelulosa bera da materialaren osagai estruktural eta nagusia, eta beste kasuetan, errefortzu gisa aritzen da material solido edo likidoen propietateak hobetzeko [36]. Hain zuzen ere, material konposatuetan, nanozelulosa kopuru txiki batekin, horien indarra eta zurruntasuna asko handitu daitezke; horregatik, nanozelulosa oso interesgarria da garraio-sektoreko eta bereziki automobilgintzarako konpositeen osagai moduan erabiltzeko, ez bakarrik propietate mekanikoengatik, baita haren pisu arinarengatik ere, beste material metaliko astunago batzuen ordez erabil baitaiteke. Konkretuki, arintasuna da gaur egun automobilgintzarako ezaugarri garrantzitsu bat, erregai-kontsumoarekin eta kutsadurarekin guztiz lotuta dagoena. Baina, arintasuna ez ezik, nanozelulosaz indartutako plastikoek erresistentzia hobea ere erakusten dute: berotasunaren, uraren, oxigenoaren edo gasolina-isurien kalteen aurkako erresistentzia.

Nahiz eta aeronautikan eta energia-industrietan materialak ordezkatzea konplexuago den, nanozelulosak beira-zuntzak edo Kevlar bidez kargatutako plastikoak ordezka ditzake etorkizunean, eta badaude lan batzuk abian horren inguruan. Hain zuzen ere, ibilgailu-ekoizleak nanozelulosa bitartez indartutako plastikoak probatzen ari dira, emaitza onak lortuz, urte gutxitan erabiltzeko asmoarekin.

Beste aplikazio-arlo bat eraikuntza da; nanozuntzak, material funtzional moduan, eraikin-blokeetan zabalki erabiltzen dira, biodegradagarri eta betegarri natural bezala, polimero konpositetan isolatzeko eta sugarra atzeratzeko ahalmenari eta jasangarritasunari esker. Hala ere, badago oraindik zer hobetu; batez ere, zelulosaren polaritate eta hidrofilia direla-eta: konpatibilitate eskasa dauka termoplastiko ez-polar eta hidrofobikoekin. Honen ondorioz, nanozelulosak dispertsio txarra eta interakzio ahulak ditu matrize eta betegarriekin. 


\subsubsection{Estaldura eta pintura}

Nanozelulosa estaldura- eta pintura-material bezala ere erabiltzen da beste material batzuen azaleko propietate mekaniko edo fisikoak hobetzeko. Nanozelulosa-zuntz monokapak deposizio fisikoaren teknikaren bitartez lor daitezke, eta kapa horiek estaldura solidoak sortzen dituzte [39].

Aplikazio honen adibide izan daitezke osagai desberdinetan motorolioaren, butanol ez-polarren edo uraren akziotik libratzeko nanozelulosa-estaldurak. Auto-garbiketaren funtzio hau ZNZen egitura molekular bakarrari esker lor daiteke, eta, hain zuzen ere, nanozelulosa-estaldura horiek porta daitezke efektibitate handiko mintz bezala, ura eta olioa bereizteko.

\subsubsection{Fluido elektrorreologikoak robotikan}

Inguru elektriko edo magnetiko baten eraginez beren egoera aldatzen duten likidoak dira fluido elektrorreologikoak. Aplikatzen zaien eremuaren intentsitatearen arabera, material horiek milisegundo gutxitan uraren moduan jario, eztiaren moduan isuri edo gelatina moduan solidotu daitezke. Fluido horiek, berez, partikula mikroskopikoak esekita dauzkaten likido isolatzaileak dira. Erabiltzen diren partikulek propietate elektriko edo erdieroaleak dituzte, eta likidoak ez-polarrak izaten dira. Hain zuzen ere, nanozelulosaren eta funtzionalizatutako nanozelulosaren propietate erdieroaleak, besteak beste, material funtzional aparta bilakatzen du suspentsio elektroerantzule edo elektrorreologikoan erabiltzeko [37].

Fluido elektrorreologikoen aplikazio berrietakoa robotikara dago zuzendua, eta konkretuki robot bigunen sorrerara; robot berritzaile horiek, ohiko aginterako sistema elektrikoak erabili ezean, mikrofluidoz osatutako zirkuitu batzuen bidez kontrolatzen dira. Osagai-aldaketa horiek bitarteko direla, gizakien mugikortasuna imita dezakete; azkarragoak izan daitezke, seguruagoak eta merkeagoak, nahiz eta oraindik gaur egun aplikazio batzuetarako gogortasuna beharrezkoa den. 


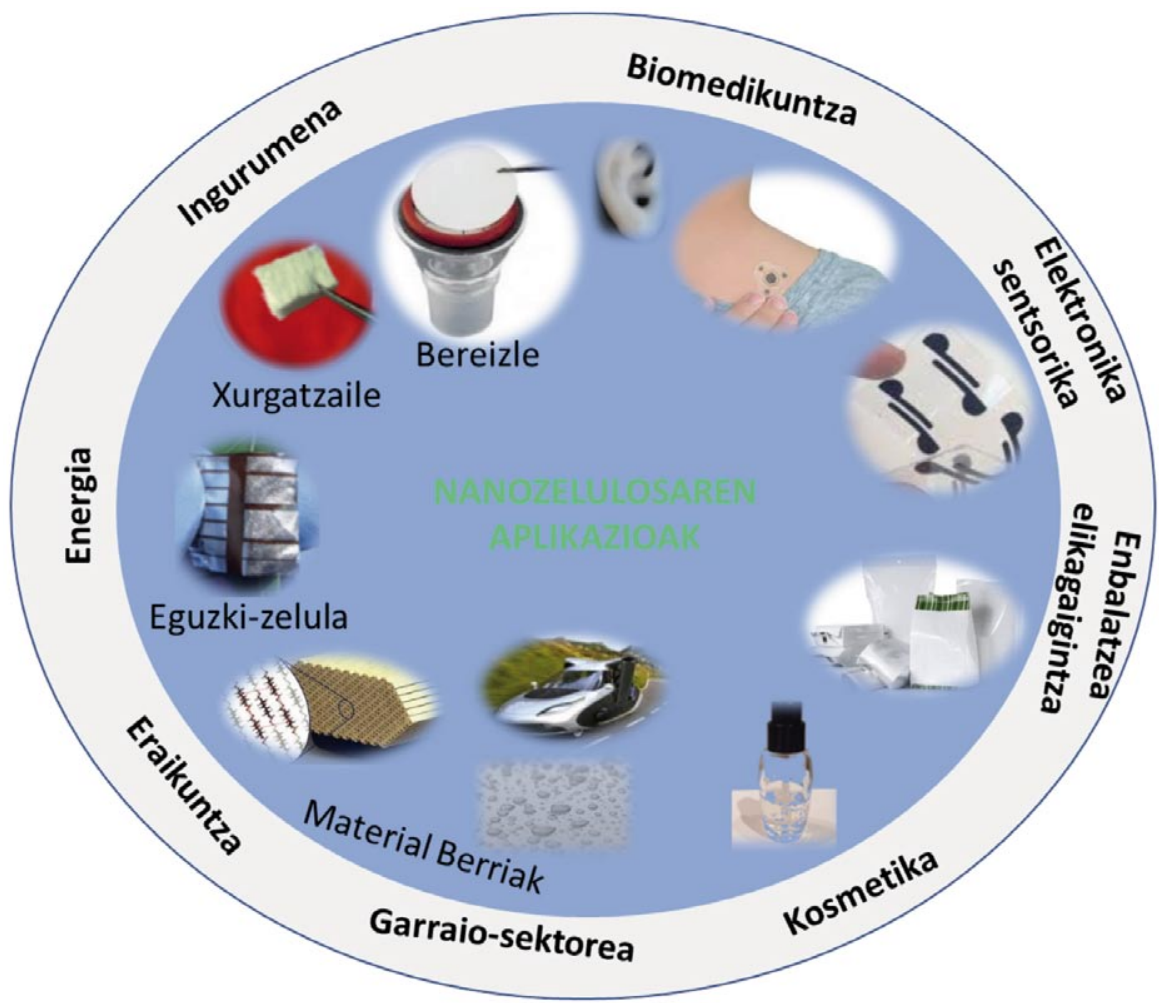

9. irudia. Nanozelulosaren aplikazio-sektore nabarmen eta berritzaileenak.

\subsection{Enbalatze industria}

Nanozelulosaren lehenengo aplikazioetarikoa enbalatze-industria izan da, bereziki elikagaigintzan, non ohiko enbalatze-materialak ordezka baititzake. Enbalatzearen helburu nagusia barnean duen produktua babestea eta haren biziraupena luzatzea da. Hasieran aipatu den bezala, gaur egun erabiltzen diren enbalaje sintetikoek ingurumenarekiko arazoak eragiten dituzte haien kopuru handiagatik eta biodegradagarritasunik ezagatik. Honen ondorioz, enbalatze-industriaren joera ohiko material sintetikoak jatorri naturaleko material biodegradagarriekin ordezkatzea da. Material horien artean, nanozelulosa eta nanozelulosa-konpositezko mintzak nabarmendu dira, erakusten duten propietate mekaniko eta hesi-propietate apartengatik [35]. Hala ere, oraindik hobekuntza- eta ikerkuntza-eremu handia dago ohiko plastikoen zenbait propietate lortzeko. 


\subsection{Industria Kimiko eta beste batzuk}

Nanozelulosa funtzionalizatua, katalisi heterogeneo berrien sostengumatrize bezala, gero eta gehiago erabiltzen da. Zentzu horretan, nanozelulosa nanopartikulen dispertsio-matrize bezala erabil daiteke. Nanozelulosan partikula horien dispertsioa altua izaten da, eta beste abantaila bat da substratuen eta material inorganikoaren arteko erreakzioak eragiten dituen kontaktua efizientea dela. Adibidez, nanozelulosaren propietate katalitiko horiek fenolaren hidrogenazioan erabiltzen dira nanopartikula bezala paladioa erabiliz [39]. Prozesu honetan inguru-tenperaturan 24 orduz egon eta gero, konbertsio-graduak \% 90ekoak izaten dira.

Azkenik, nanozelulosa elikagaigintzan ere erabiltzen da (bereziki gehigarri bezala, elikagaiak egonkortzeko eta loditzeko), eta kosmetikan, nekazaritzan edo ehungintzan, materiala osatzen duten nanozuntzen propietate aproposez baliatuta.

\section{ONDORIOAK}

Polimero biodegradagarriak eta konposite berriak lortzeko iturri aberatsenetariko eta oparoenetariko bat da zelulosa. Zelulosatik sintetizatutako nanozelulosaren moldaketaren bidez aukera desberdinak aurkitu daitezke, material mota bereizgarriak lortuz: nanokristalak eta modu oso desberdinetan sintetizatutako nanozuntzak. Honez gain, nanozelulosan oinarrituriko materialak beren egitura makroskopikoaren arabera sailkatzen baditugu, filmak, gelak eta aerogelak nabarmendu daitezke.

Aipatutako aukerei nanozelulosaren propietate bereziak gehitzen badizkiegu (alde batetik, propietate mekaniko eta fisiko apartak eta, beste aldetik, biobateragarritasuna, degradagarritasun egokia eta toxikotasunik eza, besteak beste), aplikazio-esparru handiak aurkitu ditzakegu. Bestalde, gainazal-modifikaziorako aukera izugarriak dituen materiala izanik, ezaugarri hauen guztien konbinaketari esker, gaur egun aplikazio aukera gehiago atzematen ari dira. Hala ere, nanozelulosaren inguruan, oraindik, material berriak garatzeko hobekuntza-arlo handiak daude, bai propietateak hobetzeari dagokionez eta bai aplikazio-arlo askotan, oraindik lehen urratsak soilik eman baitira.

Azkenik, nahiz eta laborategietan nanozelulosan oinarritutako materialen ikerkuntza etengabea eta arrakastatsua den, gaur egungo erronka nagusietarikoa nanozelulosan oinarritutako material eta osagaiak industriamailan eta eskala handian fabrikatzea da. Helburu hori lortzeko, prozesu jasangarri, kalitatezko eta lehiakorrak garatzea beharrezkoa da, material berriak merkatu eta sektore desberdinetara hurbiltzeko. 


\section{BIBLIOGRAFIA}

[1] ANASTAS, P. T.; \& WARNER, J. C.1998. Green chemistry: Theory and practice. Oxford University Press. New York.

[2] BAILLIE C.2004. Green Composites, Polymer composites and environment. Woodhead publishing limited, Cambridge, England.

[3] STEVENS E.S. 2002. Green plastics: an introduction to the new science of biodegradable plastics. Princeton University Press, New Jersey.

[4] FRITZ H.G.; SEIDENSTUCKER T.; BOLZ U.; JUZA M.1994. Study on production oh thermoplastics and fibers based mainly on biological materials. European Commission. Stuttgart.

[5] YOUNAS T.; ALI I.; JAMIL N.2015. «Polyhydroxyalkanoates production using canola oil by bacteria isolated from paper pulp industry». Kuwait $J$. Sci. 42 (2), 236-249.

[6] SCHNABEL, W.1981.Polymer degradation. Principles and practical applications. Ed. Hanser, Múnich.

[7] DUFRESNE, A. 2008. «Polysaccharide nano crystal reinforced nanocomposites». Canadian Journal of Chemistry, 86 (6),484-494.

[8] DUFRESNE, A. 2013. «Nanocellulose: a new ageless bionanomaterial». Materials Today 16, 6, 220-227.

[9] THAKUR V.K., KUMARI M.2015.Eco-friendly Polymer Nanocomposites: Processing and Properties. Springer India.

[10] THAKUR V.K., KUMARI M., KESSLER M.R.2017. Handbook of Composites from Renewable Materials, Nanocomposites: Science and Fundamentals. Volume 7.

[11] LI P., LIU R.,2015. «Cellulose Gels and Microgels: Synthesis, Service, and Supramolecular Interactions». Advances in Polymer Science, 268, 209-251.

[12] MISHRA R.K., SABU A., TIWARI S.K. 2018. «Materials chemistry and the futurist eco-friendly applications of nanocellulose: Status and prospect». Journal of Saudi Chemical Society.

[13] CHAE HOON KIM C.H., YOUN H.J., LEE H.L.2015. «Preparation of cross-linked cellulose nanofibril aerogel with water absorbency and shape recovery». Cellulose, 22, 3715-3724.

[14] WANG B., YANG D., ZHANG H., HUANG C., XIONG L., LUO J, CHEN X. 2016. «Preparation of Esterified Bacterial Cellulose for Improved Mechanical Properties and the Microstructure of Isotactic Polypropylene/Bacterial Cellulose Composites». Polymers,8 (4), 129-140.

[15] LIZUNDIA E. 2013.«Polimero biodegradagarrietan oinarrituriko material nanokonposatuak: Poli (L-laktida)/karbono nanotutu konpositearen kasua». Ekaia. EHUko Zientzia eta Teknologia aldizkaria (26), 2013.

[16] LIZUNDIA E.; URRUCHI A., VILAS J., LEÓN L.M. 2016. «Increased functional properties and thermal stability of flexible cellulose nanocrystal/ ZnO films». Carbohydrate Polymers, 136, 250-258. 
[17] GOIKURIA U., LIZUNDIA E., LARRAÑAGA A., VILAS J.L. 2017. «Thermal stability increase in metallic nanoparticles-loaded cellulose nanocrystal nanocomposites». Carbohydrate Polymers, 171,193-201.

[18] SIQUEIRA G.; BRAS J., DUFRESNE A. 2008. «Cellulose whiskers versus microfibrils: Influence of the nature of the nanoparticle and its surface functionalization on the thermal and mechanical properties of nanocomposites». Biomacromolecules, 10 (2), 425-432.

[19] SOYKEABKAEW N., SIAN C., GEA S., NISHINO, T., PEIJS, T. 2009 «All-cellulose nanocomposites by Surface selective dissolution of bacterial cellulose». Cellulose, 16 (3), 435-444.

[20] FILPPONEN I., ARGYROPOULOS D.S. 2010. «Regular linking of cellulose nanocrystals via click chemistry: Syntesis and formation of cellulose nanoplatelet gels». Biomacromolecules, 11, 1060-1066.

[21] DE FRANCE K.J., HOARE T., CRANSTON E.D. 2017. «Review of Hydrogels and Aerogels Containing Nanocellulose». Chem. Mater.,29, 46094631.

[22] GOLMOHAMMADI H., MORALES-NARVAEZ E., NAGHDI T., MERKOCI A. 2017. «Nanocellulose in Sensing and Biosensing». Chemistry of Materials, 19 (13),5426-5446.

[23] STEVANIC J. S.; JOLY C., MIKKONEN K. S.; PIRKKALAINEN K., SERIMAA R.; RÉMOND C.; SALMÉN L. 2011. «Bacterial nanocellulosereinforced arabinoxylan films». J. Appl. Polym. Sci., 122(2), 1030-1039.

[24] REZAIE.H.R., BAKHTIARI 1., OCHSNER A. 2015. Biomaterials and their Applications. Springer International Publishing.

[25] SUMAN KARDAM A.; GERA M.; JAIN V. 2015. «A novel reusable nanocomposite for complete removal of dyes, heavy metals and microbial load from water based on nanocellulose and silver nanoembedded pebbles». Environ. Technol., 36 (6), 706-714.

[26] SUOPAJÄRVI T., LIIMATAINEN H., KARJALAINEN M., UPOLA H.; NIINIMÄKI, J.2015. «Lead adsorption with sulfonated wheat pulp nanocelluloses». J. Water Proc. Eng., 5, 136-142.

[27] WANG Y.; YADAV S.; HEINLEIN T., KONJIKA V., BREITZKEC H., BUNTKOWSKYC G., SCHNEIDER J.J.; ZHANG K. 2014. «Ultra-light nanocomposite aerogels of bacterial cellulose and reduced graphene oxide for specific absorption and separation of organic liquids». RSC Adv., 4, 2155321558.

[28] THAKUR V.K., VOICU S.I. 2016. «Recent advances in cellulose and chitosan based membranes for water purification: A concise review». Carbohydrate Polymers, 146,148-165.

[29] LIZUNDIA E., NGUYEN T., VILAS J.L., HAMAD W.Y., MACLACHLAN M.J. 2017. «Chiroptical, morphological and conducting properties of chiral nematic mesoporous cellulose/polypyrrole composite films». J. Mater. Chem. A, 5, 979-987. 
[30] ALARCON C.D.L.H., PENNADAM S., ALEXANDER C.2005. «Stimuli responsive polymers for biomedical applications». Chem Soc Rev, 34 (3),276-285.

[31] LIZUNDIA E., GOIKURIA U. VILAS J.L, CRISTOFARO F., BRUNI G., FORTUNATI E., ARMENTANO I., VISAI L., TORRE L..2018. «Metal Nanoparticles Embedded in Cellulose Nanocrystal Based Films: Material Properties and Post-use Analysis». Biomacromolecules, DOI: 10.1021/acs. biomac.8b00243

[32] SAHAR SULTAN S., MATHEW A.P. 2018. «3D printed scaffolds with gradient porosity based on a cellulose nanocrystal hydrogel». Nanoscale, $\mathbf{1 0}$, 4421-4431.

[33] LIZUNDIA E., DELGADO-AGUILAR M., MUTJE P., FERNANDEZ E. ROBLES-HERNANDEZ, B., DE LA FUENTE, M.R. VILAS, J. L., LEON, L. M. 2016. «Cu-coated cellulose nanopaper for green and low-cost electronics». Cellulose, 23, 1997-2010.

[34] LIZUNDIA E., NGUYEN T., VILAS J.L., HAMAD W.Y., MACLACHLAN M.J. 2017. «Chiroptical luminescent nanostructured cellulose films». Mater. Chem. Front.,1, 979-987.

[35] LIZUNDIA E., FORTUNATI E., DOMINICI F., VILAS J.L., LEÓN L.M., ARMENTANO I., TORRE L., KENNYJ.M. 2016. «PLLA-grafted cellulose nanocrystals: Role of the CNC content and grafting on the PLA bionanocomposite film properties». Carbohydrate Polymers, 142,105-113.

[36] PLUGIA D., FORTUNATI E., KENNY J.M.2016. Multifunctional Polymeric Nanocomposites Based on Cellulosic Reinforcements. Elsevier. William Andrew Applied Science Publishers.

[37] CHOI K., GAO G. Y., NAM J.D., CHOI H.J..2017. «Cellulose-Based Smart Fluids under Applied Electric Fields» Materials,10,1060.

[38] LAVOINE N., BERGSTRÖM L. 2017. «Nanocellulose-based foams and aerogels: processing, properties, and applications». J. Mater. Chem. A, $\mathbf{5}$, 16105-16117.

[39] WEI H., RODRIGUEZ K., RENNECKAR S., VIKESLAND P.J. 2014. «Environmental science and engineering applications of nanocellulose-based nanocomposites» Environ. Sci.: Nano,1, 302-316. 